\title{
Traditional games: improving manners through carom
}

\section{Achmad Miftachul 'Ilmi, Djoko Budi Santoso, Muslihati}

\author{
Universitas Negeri Malang, Malang Indonesia \\ miftachulilmi199931@gmail.com
}

Submitted : 28-04-2020, Revised : 18-05-2021, Accepted : 29-05-2021

\begin{abstract}
In the era of the industrial revolution 4.0, there was a decline in the character of the Indonesian nation, such as manners and less commendable individual behaviour. Hence, the importance of strategies for enhancing and developing individual manners. The purpose of this research is to produce a guidebook and play media of $\mathrm{Si}$ KARTUN to develop the manners of junior high school students. The research and development method used was adapted from the Borg \& Gall model. The research and development subjects consist of two media experts, one material expert, and two potential users (mentors). Expert and prospective user test tools use a product acceptance scale based on aspects of accuracy, function, interest, and accuracy in providing group guidance services to foster the behaviour of junior high school students. Data analysis of material experts and candidates used the inter-rater agreement model while the results of the media evaluation were analyzed on an average basis. Based on the evaluation results of experts and potential users, Si-KARTUN meets the appropriate criteria, is practical, attractive, and easy to use; Therefore, the Si-KARTUN product is feasible to be applied. By using the SiKARTUN product, the guidance process is much more fun and interesting.
\end{abstract}

Keywords: Carom; Manners; Traditional Game

\section{Introduction}

Nowadays, it has come into the 4.0 industry revolution era. It causes the invulnerable flow of globalization along with rapid science and technology development (Saputri, 2017). The existence of Covid-19 and all policies made by the government has also contributed to the change of all life sectors. The United Nations assumes that education is one of the sectors getting affected by the pandemic. According to the data assembled by UNESCO, at least 290.5 million students in the world gets disturbance in their learning activities because of the school closing (Purwanto et al., 2020), whereas, education grabs the important roles to prepare the next generation as the nation character reflection (Sipayung, 2018). This important role includes the development of courtesy and the cognitive abilities of students.

A decrease in manners is a problem that occurs in this era. The difficult thing that education understands is teaching manners to individuals through technology. According to Gultom (2019) the individual behaviour and the lack of manners have become the evidence of Indonesian character degradation caused by technology impact. The research result conducted by Febrianti et al (2020) states that the manners degradation has been encountered by a junior high school in Bandar students. Furthermore, there are 50\% of seventh graders of junior high school 1 Colomadu often speak too loud, swear, and behave impolitely to the teacher (Wahyuni, 2019). The lack of manners behaviour also found in the students of junior high school in Banjarmasin in which some of the students do not talk politely nor greet the teacher, and often fight with their friends (Syahid, 2020).

The facts discovered reflect that the ethical behaviour related to manners on junior high school students is still at a low level (Febrianti et al., 2020; Syahid, 2020; Wahyuni, 2019). Based on the interview result conducted by two counsellors of junior high school 23 Malang, it is gained that the guidance and counselling services about manners are important to be given in this era, especially manners to teachers, parents, and friends. The counsellor of junior high school 23 Malang has provided classical guidance service of manners to the seventh graders with the technique of expository and question and answer. However, the attempt done perceived not to be optimal proven by the online learning done lately. Various students are 
absent, passive during learning activities, and cannot communicate with the teachers well through social media. The implementation of online learning can be effective if it is planned with a carefully thought out strategy and a more active approach that can measure various aspects (Bączek et al., 2021).

The aspects that must be considered in the learning process are adjusted to the level of development. For example, in adolescents, cognitive development enters the formal operational stage which makes critical (Piaget, 2013); unstable emotional development (Purwaningtyas, 2020); in the moral aspect of students already understanding the norms that apply in society (Kemdikbud, 2016). Therefore, it is very necessary to provide information about courtesy so that student behaviour is by applicable norms.

As stated by Saputri (2017), manner is interpreted as personal behaviour that considers the good values of honouring, respecting, and a noble character as social demands in society. Manner is constructed from the habits of the society in a particular place which becomes the spoken habit and the ones who break it will receive moral sanctions (Andika, 2019; Kholifah \& Naimah, 2017; Suryani, 2017). Based on Student Independence Standards about ethical behaviour basis, the student is required to perceive the reasons the significance in obeying the rules, understanding various rules to behave, and being able to consider self-consideration of applied norms in the society (Santoso, 2013).

The implementation of guidance services can use various strategies to reinforce the participation and motivations of the students in involving the activities. According to Putri (2019), a group guidance strategy enables the students to comprehend each other's thought and interpret togetherness in the group dynamics. The guidance group can be performed by at least five to ten students in a group. Benefits of the guidance group are establishing positivity toward students' circumstance and their environment connected with things they talk about among the group members (Bakhtiar et al., 2018; Mittelmeier et al., 2018). It is appropriate with the purpose of giving the service about manner skill.

Simulation game method is the method that frequently recommended to be used as group guidance method in developing manners (Putri, 2019). One of the successful determinants in utilizing the simulation game method is the medium used. The media in counselling services will facilitate and make counselling services attractive (Larberg \& Sherlin, 2021; Yuniarti \& Asrowi, 2021). Media provide a new way to transfer knowledge that can be of interest to adolescents.

The past lives of the pupils that were untouchable from outside the world have led children to cooperate in a particular social activity. One of the occasions is the traditional game usage. Through playing the traditional game, one can express themselves, therefore, it can escalate one creativities and skills that will support the triumph in adapting toward their environment (Ramadhani, 2018; Irman, 2017). One of the appropriate games that suit junior high school students to grow their manners is carom. Carom is valued to be able to influence well in helping students to grow their emotional and social skills (Saputra \& Ekawati, 2017). Carom is also able to escalate patient and honour values among players proven in the scrolling system (Nugrahastuti et al., 2016).

Based on the results of preliminary research conducted on 25 August-30 October 2020, a strategy is needed in developing student manners. Therefore, the researcher developed SiKARTUN (Carom Sopan Santun) media with group guidance strategies and simulation game techniques to foster the behaviour of junior high school students. 


\section{Method}

This research and development use the Borg \& Gall model. The research steps are limited according to the needs of the researcher, namely: (1) problem determination, (2) development planning, (3) product design development, (4) product validation, and (5) product revision.

This research begins with a literature study and data collection is carried out through interviews and observations; create a conceptual design for Si-KARTUN products based on the stages of determining the problem; determination of product objectives for data; preparation of products and assessment instruments in the form of a counsellor manual and Si-KARTUN media, as well as a questionnaire; then product validation. At this stage of validation, two material experts, one media expert, and two potential counsellor users are obtained; Product revisions are based on validation of experts and potential users, so that the final product is produced in the form of a guidebook and Si-KARTUN media.

The results of the expert and prospective user test assessments use the inter-rateragreement model, while the average score analysis is used for the media expert test. The four aspects used as a reference for the assessment are aspects, function, convenience, accuracy, and interest. Qualitative analysis techniques are obtained from experts and potential users through criticism and suggestions written in expert and potential user test instruments. The criticism and suggestions given were obtained by researchers to improve Si-KARTUN products.

\section{Results and Discussion}

The result of this research and development is in the form of a counsellor guidance book and Si-KARTUN medium to grow the manners of junior high school students. Theoretically, the product is eligible to be implemented according to the experts and potential user testing results. The product of Si-KARTUN has been validated by two guidance and counselling material experts, one media expert, and two potential users (counsellors). The two experts give high relevance toward 33 question points. The assessment result obtained reaches an expert testing agreement index of 1 meaning the validity is considered very high. The prospective user test also gets an agreement index which has high validity. Therefore, it can be concluded that the product accomplishes appropriate, practical, fascinating, and easy to use in providing group guidance services using simulation game technique with Si-KARTUN as the medium to grow the manners of junior high school students.

The product assessment of Si-KARTUN is also based on the criticism and suggestions by material experts, media, and potential users. According to the criticism and suggestions given, there are several revisions done which are (1) adding subtitle in the table of content inside the guidance book, (2) giving the explanation of the function of the gaucho chip inside the guidance book, (3) conforming the font and changing the font type from times new roman to Rajdhani, (4) adding on the group discussion after playing Si-KARTUN, (5) changing the expression of the student illustrations on the guidance book cover to reflect happiness and manners, (6) Adding on the guidance about the utilization of Si-KARTUN medium to growthe manners of junior high school students in the form of powerpoint file. 

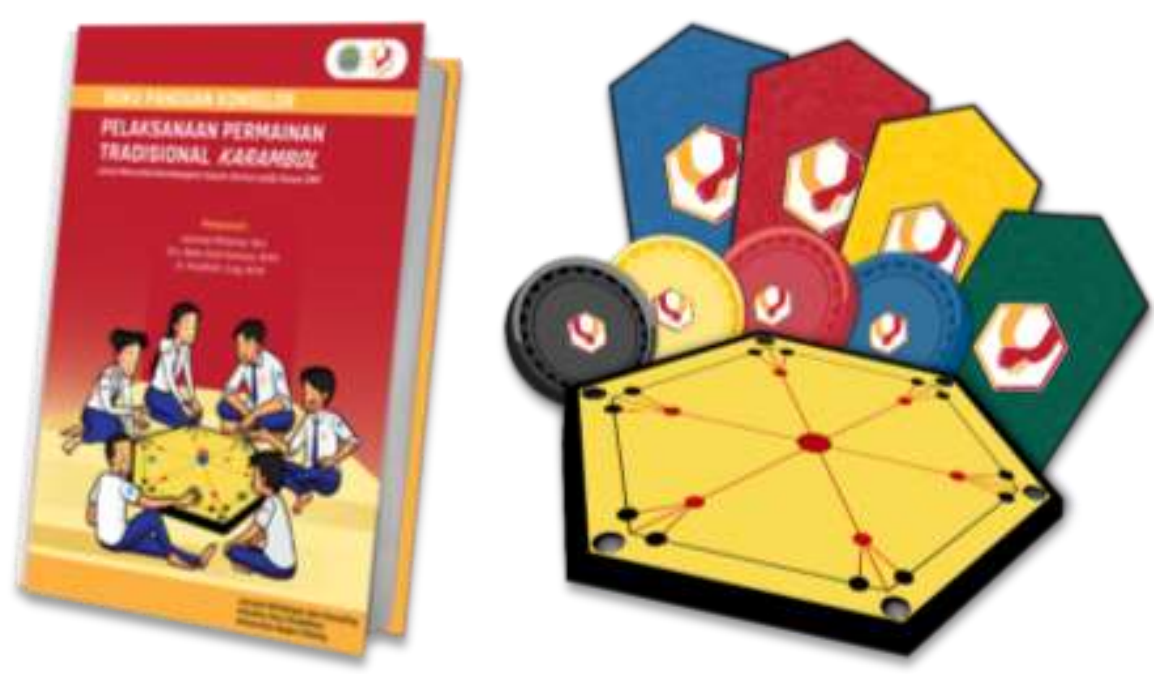

Figure 1. Guidance Book and Si-KARTUN Product

According to all material expert, media expert, and potential user testing results, the product of Si-KARTUN has a very high validation, thus, the product is considered very accurate, very beneficial, very interesting, and very easy to use in providing group guidance services using simulation game technique with Si-KARTUN as the medium to grow the manners of junior high school students. All product design is created by using adobe photoshop cc 2018 and adobe illustrator cc 2018 applications. The product design created interestingly aims to interest students in using the media (Rusli et al., 2019). All the product design is adjusted with manner themes and Javanese cultures. Manner themes are applied in every playing card through icons; moreover, there is an illustration in the guidance book reflecting the harmony of a friendship of junior high school students in playing carom. On the other hand, the application of Javanese culture themes are found in every product design ornament utilizing batik patterns explicitly. The adjustment of the visual and the material aspects is considered to help students in obtaining new knowledge (Wang, 2021; Vagg et al., 2020).

The development of guidance book is aim at easing counselor in providing guidance and counseling services (Savitri et al., 2020; Anja, 2019). The counselor guidance book using carrom traditional game as the media to grow the manners of junior high school students is arranged densely and clearly in order to ease the users in in understanding the contents in the book. The results also prove that the use of traditional game media can be used as an intermediary that can be used by the teacher to provide learning (Agusti et al., 2018). The guidance book developed has 34 pages consisting of some parts which are (1) chapter I introduction describing about background of the problem, general and specific purposes, and the target users of the guidance book, (2) chapter II describing about the way to grow the manners through the traditional game with Si-KARTUN as the medium, and (3) chapter III describing about the guidance of the guidance book. Furthermore, Si-KARTUN medium has components consisting (1) a board in the shape of hexagon, (2) four types of carom chips consisting 12 blue question chips, 6 red challenge chips, two yellow special chips, and one black gacho chip, and (3) four types of game cards consisting 10 role cards, 12 blue question cards, 6 red challenge cards, and 2 yellow special cards.

The implementation of Si-KARTUN utilizes group guidance with simulation game technique. The group guidance strategy is believed to help students comprehending each other, interpreting togetherness in group dynamics, and establishing positivity toward things they talk among the group members (Putri, 2019; Romlah, 2013). In addition, the emotional aspects of group activities are easier to build and make individuals understand how they should behave (Pramudyani, 2020). Furthermore, in the simulation game technique, students is required to learn 
unconsciously, thus, various experiences during the game they will gain and be able to implement them on their daily life (Putri \& Ramli, 2016). The implementation of simulation game technique requires a medium to engage students in order not to get easily bored in accomplishing the activities, thus, the topic or material given will be internalized well by each student (Fitriani, 2019). This shows that the use of Si-KARTUN media in groups to develop manners is very appropriate.

The carom game developed in this study feels very appropriate in developing individual manners. The carom game fosters behaviour in each player, by playing carom, students will increase the value of patience and respect for other players as evidenced by the rolling game system (Asisningtyas, 2017; Márkus et al., 2018; Zhao et al., 2017). Carom is also considered to have a major influence in helping students develop emotional and social skills (Saputra, N. E dan Ekawati, 2017).

Based on the simulation game technique, there are several modifications in the $\mathrm{Si}$ KARTUN game compared to the common carom. The modifications are done aim to make the guidance service provision being implemented well. This is by the opinion that the game as a media game becomes interesting (Cahyani et al., 2017; Garris et al., 2017). The modifications on Si-KARTUN medium are: (1) The hexagon shape with $100 \mathrm{~cm}$ in diameter that aims at being played by up to ten students; (2) The game cards with $6 \mathrm{~cm} \times 10 \mathrm{~cm}$ in size consisting of role cards, question cards, challenge cards, and special cards; (3) Game chips that have $0.6 \mathrm{~cm}$ thickness and $3.2 \mathrm{~cm}$ diameter consisting question, challenge, special, and gacho chips that are functioned as the flick in the game; (4) The playing procedures in utilizing Si-KARTUN medium is adjusted to the steps in simulation game technique.

The material developed in the Si-KARTUN medium is manners to parents, teachers, and friends. The choice of the materials is based on the result of a preliminary study conducted in SMPN 23 Kota Malang. The five indicators used to develop Si-KARTUN are (1) hospitality to anyone, (2) showing friendly and organized expressions, (3) showing sympathy and empathy, (4) able to control oneself in behaving, and (5) having a high tolerance (Andika, 2019; Sukini, 2016; Zuriah, 2015). In the Si-KARTUN game, the players are considered to win if they can collect the most carom chips during the determined time. However, during the game, the players can take several chips that have been inserted into the carom bag if they are accomplishing the command from the game cards.

The utilization of Si-KARTUN medium to grow the manners of junior high school students is held in three meetings. Each meeting has different and gradual topic to help internalizing the materials given. Different topics for each meeting make it easier for individuals to understand the material provided and understand the values given (Pramono, 2020; Stålhammar \& Pedersen, 2017).

According to all testing done by the researcher, it reaches a result that the advantage of Si-KARTUN is arranged by the need analysis and validated by three expert lecturers and two counselor potential users. Other than that, the implementation of Si KARTUN has held three meetings with a different topic for each meeting. The main purpose in the final meeting is the group members can implement the manners in their daily life. The materials provided on the game cards also based on the affairs that happened around family, school, and social environments. The disadvantage of Si-KARTUN is in the development steps in which it ends on the product revision from potential users that are counsellors of junior high school 23 Malang. It is because the development of the Si-KARTUN medium is based on the need analysis in junior high school 23 Malang. 


\section{Conclusions and Suggestions}

Based on all research steps done, the final result produces the guidebook and $\mathrm{Si}$ KARTUN medium. It is expected that the existence of Si-KARTUN product can be the alternative in providing group guidance services using simulation game technique to grow the manners of junior high school students. The research and development of Si-KARTUN done are still in the step of potential user expert testing (counsellors). Therefore, the effectiveness testing related to the media utilization of Si-KARTUN to grow the manners of junior high school students using group guidance strategy and simulation game technique is required.

\section{References}

Agusti, F. A., Zafirah, A., Engkizar, E., Anwar, F., Arifin, Z., \& Syafril, S. (2018). The Implantation of Character Values toward Students through Congkak Game for Mathematics Instructional Media. Jurnal Penelitian Pendidikan, 35(2), 132-142.

Andika, R. (2019). Penggunaan Teknik Konseling Humanistik Melalui Layanan Bimbingan Kelompok Untuk Meningkatkan Sopan Santun Siswa Kelas VIII SMP PAB Helvetia Medan TA 2018/2019. Universitas Muhammadiyah Sumatera Utara.

Anja, N. (2019). Pengembangan Panduan Permainan Simulasi Ular Tangga untuk Meningkatkan Academic Hardiness Siswa SMP. SKRIPSI Jurusan Bimbingan Dan Konseling \& Psikologi-Fakultas Ilmu Pendidikan UM.

Asisningtyas, Y. (2017). Pengaruh Penggunaan Media Karambol terhadap Hasil Belajar Materi Gaya Siswa Kelas V SD. Jurnal Penelitian Pendidikan Guru Sekolah Dasar, 5(3), 1387-1395.

Bączek, M., Zagańczyk-Bączek, M., Szpringer, M., Jaroszyński, A., \& Wożakowska-Kapłon, B. (2021). Students' perception of online learning during the COVID-19 pandemic: a survey study of Polish medical students. Medicine, 100(7).

Bakhtiar, A., Webster, E. A., \& Hadwin, A. F. (2018). Regulation and socio-emotional interactions in a positive and a negative group climate. Metacognition and Learning, 13(1), 57-90.

Cahyani, N. A. P., Bariyyah, K., \& Latifah, L. (2017). Efektivitas teknik permainan simulasi dengan menggunakan media dart board untuk meningkatkan motivasi belajar siswa kelas VII C SMP Negeri 2 Tegal Siwalan Probolinggo. JKI (Jurnal Konseling Indonesia), 3(1), 22-27.

Dzhashitov, V. E., Pankratov, V. M., \& Golikov, A. V. (2012). An Innovative Multimedia Learning Method As Applied to Theoretical Mechanics and Theory of Gyroscopes. IFAC Proceedings Volumes, 45(11), 39-44.

Febrianti, F., Yanti, R., \& Noverita, A. (2020). Analisis Degradasi Moral Sopan Santun Siswa di SMP Negeri 01 Bandar. Jurnal Ilmiah Mahasiswa, 1(1), 1-10.

Fitriani, E. (2019). Peranan Layanan Bimbingan Kelompok dalam Mengendalikan Emosi dan Etika Komunikasi Siswa SMP Swasta Silinda. Jurnal Pendidikan Dan Pembelajaran Terpadu (JPPT), 1(2), 93-105.

Garris, R., Ahlers, R., \& Driskell, J. E. (2017). Games, motivation, and learning: A research and practice model. In Simulation in Aviation Training (pp. 475-501). Routledge.

Gultom, E. L. (2019). Pengembangan Bahan Ajar Berbasis Karakter Peduli Sosial Berdasarkan Nilai Spiritualitas Fransiskan Dengan Strategi Contextual Teaching And Learning. Pendidikan Dasar Pascasarjana. Universitas Negeri Medan.

Irman, I. (2017). Nilai-Nilai Karakter pada Anak Dalam Permainan Tradisionan dan Moderen. KONSELI: Jurnal Bimbingan Dan Konseling (E-Journal), 4(2), 89-96.

Kemdikbud. (2016). Panduan Operasional Penyelenggaraan Bimbingan dan Konseling Sekolah Menengah Pertama (SMP). 
Kholifah, K., \& Naimah, T. (2017). Studi tentang sopan santun pada peserta didik. JSSH (Jurnal Sains Sosial Dan Humaniora), 1(1).

Larberg, J. L., \& Sherlin, L. H. (2021). Grit and Growth Mindset Contribution to School Counseling Services. SAGE Open, 11(2), 21582440211014510.

Márkus, Z. L., Kaposi, G., Veres, M., Weisz, Z., Szántó, G., Szkaliczki, T., PanevaMarinova, D., Pavlov, R., Luchev, D., \& Goynov, M. (2018). Interactive Game Development to Assist Cultural Heritage. Digital Presentation and Preservation of Cultural and Scientific Heritage, 8, 71-82.

Mittelmeier, J., Rienties, B., Tempelaar, D., \& Whitelock, D. (2018). Overcoming crosscultural group work tensions: Mixed student perspectives on the role of social relationships. Higher Education, 75(1), 149-166.

Nugrahastuti, E., Pupitaningtyas, E., Puspitasari, M., \& Salimi, M. (2016). Nilai-nilai Karakter pada Permainan Tradisional. Prosiding Seminar Nasional Inovasi Pendidikan, $265-273$.

Piaget, J. (2013). Child's Conception of Space: Selected Works (4th ed.). Routledge.

Pramono, A. (2020). Meningkatkan Kecerdasan Emosional Melalui Layanan Bimbingan Kelompok Teknik Problem Solving. Jurnal Prakarsa Paedagogia, 3(1).

Pramudyani, A. V. R. (2020). Traditional Game of Ular Naga for Early Childhood Development from Teacher's Perspective. Aulad: Journal on Early Childhood, 3(1), 813.

Purwaningtyas, F. D. (2020). Intervensi Psikologi Perilaku Maladaptive: Metode CBT pada Penderita Fobia Kolam Renang atau Pantai (Air). PSIKOSAINS (Jurnal Penelitian Dan Pemikiran Psikologi), 15(1), 1-31.

Purwanto, A., Pramono R., Asbari, M., Santoso P. B., Wijayanti L. M., Hyun C. C., Putri, R. S. (2020). Studi Eksploratif Dampak Pandemi COVID-19 Terhadap Proses Pembelajaran Online di Sekolah Dasar. Journal of Education, Psychology and Counseling, 2(1), 1-12.

Putri, S. A., \& Ramli, M. (2016). Pengembangan media permainan simulasi ular tangga untuk meningkatkan tanggung jawab belajar siswa SMP. Jurnal Kajian Bimbingan Dan Konseling, 1(1), 40-46.

Putri, R. D. (2019). Bimbingan Kelompok Menggunakan Permainan Sebagai Strategi Dalam Mengembangkan Empati Siswa. Jurnal Bimbingan Dan Konseling Borneo, 1(2), 7-12.

Ramadhani, A. (2018). Identifikasi nilai-nilai pendidikan karakter dalam permainan anak tradisional. Prosiding Seminar Nasional IPTEK Olahraga (SENALOG), 1(1).

Romlah, T. (2013). Teori dan Praktek Bimbingan Kelompok. Universitas Negeri Malang.

Rusli, M., Hermawan, D., Supuwiningsih, N. N., \& Bali, S. (2017). Multimedia

Pembelajaran yang Inovatif: Prinsip Dasar dan Model Pengembangan. Penerbit Andi.

Santoso, D. B. (2013). Dasar-Dasar Bimbingan dan Konseling. Universitas Negeri Malang.

Saputra, N. E dan Ekawati, Y. N. (2017). Permainan Tradisional Sebagai Upaya Meningkatkan Kemampuan Dasar Anak. Jurnal Psikologi Jambi, 2(2), 48-54.

Saputra, N. E., \& Ekawati, Y. N. (2017). PERMAINAN TRADISIONAL SEBAGAI UPAYA MENINGKATKAN KEMAMPUAN DASAR ANAK: Nofrans Eka Saputra, Yun Nina Ekawati. Jurnal Psikologi Jambi, 2(2), 47-53.

Saputri, D. A. (2017). Pergeseran Interaksi Mahasiswa Universitas Negeri Yogyakarta dengan Lingkungan Teman Sebaya Melalui Smartphone. E-Societas. E-Societas, 6(3), $1-19$.

Savitri, R., Setiyowati, A. J., \& Atmoko, A. (2020). Pengembangan Panduan Bimbingan Kelompok Dengan Strategi Self Reinforcement Untuk meningkatkan Disiplin Belajar Siswa SMP Muhammadiyah 1 Malang. Prosiding Seminar Nasional Bimbingan Dan Konseling Universitas Negeri Malang, 23-29. 
Sipayung, R. W. (2018). Improving Students' Achievement in Reading Descriptive Text through Reciprocal Teaching Strategy. Budapest International Research and Critics in Linguistics and Education (BirLE) Journal, 1(2), 29-48.

Stålhammar, S., \& Pedersen, E. (2017). Recreational cultural ecosystem services: How do people describe the value? Ecosystem Services, 26, 1-9.

Sukini. (2016). Santun. Relasi Inti Media.

Suryani, L. (2017). Upaya Meningkatkan Sopan Santun Berbicara Dengan Teman Sebaya Melalui Bimbingan Kelompok. E-Jurnal Mitra Pendidikan, 1(1), 112-124.

Syahid, A. (2020). Studi Layanan Bimbingan Kelompok Terhadap Perilaku Sopan Santun Siswa pada Kelas VIIIC SMP Negeri 18 Banjarmasin. Jurnal Mahasiswa BK An-Nur: Berbeda, Bermakna, Mulia, 6(4), 5-9.

Vagg, T., Balta, J. Y., Bolger, A., \& Lone, M. (2020). Multimedia in Education: What do the Students Think? Health Professions Education, 6(3), 325-333.

Wahyuni, A. D. (2019). Pengaruh Layanan Bimbingan Kelompok terhadap Sopan Santun Siswa Kepada Guru (Penelitian pada Kelas VIII SMP N 1 Colomadu Tahun Pelajaran 2017/2018). Medikons: Jurnal Prodi Bimbingan Dan Konseling Unisri Surakarta, 4(1).

Wang, Y. (2021). Multimedia Technology Embedded Processor Optimizing Physical Education Teaching Innovation Under Internet Environment. Microprocessors and Microsystems, 104086.

Yuniarti, W., \& Asrowi, M. Y. (2021). The Need of Counseling Services in Pandemic Covid19 for Vocational Students. Annals of the Romanian Society for Cell Biology, 25(6), 3333-3342.

Zhao, K., Ferguson, E., \& Smillie, L. D. (2017). Individual differences in good manners rather than compassion predict fair allocations of wealth in the dictator game. Journal of Personality, 85(2), 244-256.

Zuriah, N. (2007). Pendidikan Moral \& Budi Pekerti dalam Presepektif Perubahan. Bumi Aksara. 